\title{
Two new species of Clestobothrium (Cestoda: Bothriocephalidea), parasites of Merluccius australis and M. hubbsi (Gadiformes: Merlucciidae) from the Patagonian shelf of Argentina, with comments on Clestobothrium crassiceps (Rudolphi, 1819)
}

\author{
Alicia A. Gil de Pertierra ${ }^{1}$, Inés S. Incorvaia ${ }^{2}$ and Nathalia J. Arredondo ${ }^{1}$ \\ ${ }^{1}$ Laboratorio de Helmintología, Departamento de Biodiversidad y Biología Experimental, Facultad de Ciencias Exactas y \\ Naturales, Ciudad Universitaria, Int. Güiraldes 2160, Pabellón II, 4 Piso, C1428EGA - Buenos Aires, Universidad de Buenos \\ Aires, Argentina; \\ ${ }^{2}$ Instituto Nacional de Investigación y Desarrollo Pesquero (INIDEP), Paseo Victoria Ocampo No 1, Escollera Norte, B7602HSA, \\ Mar del Plata, Argentina
}

\begin{abstract}
Two new species of bothriocephalidean cestodes, Clestobothrium splendidum sp. n. from Merluccius australis (Hutton) and Clestobothrium cristinae sp. n. from Merluccius hubbsi Marini from the Patagonian shelf of Argentina, are described. Clestobothrium splendidum can be typified by the following characteristics: a medium-sized strobila composed of 410-528 proglottides that are much wider than long; 49-90 testes per mature proglottis, partially surrounding the ovary posteriorly; a transversely elongated genital pore situated anterior to spurious articulations; presence of a genital atrium; a globular cirrus-sac occupying 4-6\% of mature proglottis width; a vagina with sphincter and three pairs of osmoregulatory canals on each side of the proglottis. Clestobothrium cristinae is characterised by its small size; 71-219 proglottides; 39-64 testes per mature proglottis, usually surrounding completely the ovary posteriorly; a rounded genital pore situated at the same level of spurious articulations; an oval cirrus-sac occupying $8-16 \%$ of mature proglottis width; and three pairs of osmoregulatory canals on each side of the proglottis. Clestobothrium cristinae shares with $C$. splendidum the type and distribution of microtriches, except for the central surface delimited by two lips. Additionally, type and voucher materials of Clestobothrium crassiceps (Rudolphi, 1819) from Merluccius merluccius were studied. A key to species is provided.
\end{abstract}

Keywords: Bothriocephalidae, Clestobothrium splendidum, Clestobothrium cristinae, Clestobothrium crassiceps, Merluccius australis, Merluccius hubbsi, key to species, Patagonian shelf, Argentina

The genus Clestobothrium Lühe, 1899 is mainly widespread among the Gadiformes. Clestobothrium crassiceps (Rudolphi, 1819), the type species of the genus, was described parasitizing the European hake Merluccius merluccius (L.) in the Mediterranean Sea near Naples (Rudolphi 1819), but it was reported in other fish hosts and localities (Cooper 1918, Wardle 1935, Yamaguti 1959, Protasova 1977, Schmidt 1986). Cooper (1918) recorded C. crassiceps from Merluccius bilinearis (Mitchill) in the north-west Atlantic near the coasts of Canada and USA, and gave a meticulous description of the species. Later, numerous authors recorded Clestobothrium sp. and/or C. crassiceps parasitizing Merluccius australis (Hutton), M. gayi (Guichenot) and M. hubbsi Marini (e.g. Szidat 1955, Carvajal et al. 1979, Fernández 1985, Reimer 1993, MacKenzie and Longshaw 1995, Sardella and Timi 1996, 2004, Oliva and Ballón 2002, George-Nascimento 2005). Clestobothrium crassiceps was also found in Macruro- nus magellanicus Lönnberg (Merlucciidae) (Oliva 2001) and Aphos porosus (Valenciennes) (Batrachoidiformes) (Cortés and Muñoz 2009) from the continental shelf of South America. Most of the works mentioned above were carried out in ecological, biogeographic or fishery contexts, where parasites are used as tools for the identification of fish stocks rather than the subject of taxonomic studies. The presence of a new Clestobothrium species parasitizing Merluccius hubbsi was suggested and briefly discussed only by Szidat (1955).

The aim of the present work is to determine the taxonomic status of Clestobothrium species parasitizing Merluccius australis and M. hubbsi from the Patagonian shelf of Argentina on the basis of detailed descriptions and drawings, and to add new information concerning the microthrix pattern. Additionally, type and voucher material of Clestobothrium crassiceps from M. merluccius was studied. A key to species is provided. 


\section{MATERIALS AND METHODS}

A total of 36 Merluccius specimens (Gadiformes: Merlucciidae) were captured by trawl and examined for cestode parasites. Merluccius australis was caught from the Patagonian shelf of Argentina (Atlantic Ocean) $\left(52^{\circ} 20^{\prime}-54^{\prime} \mathrm{S} ; 64^{\circ} 36^{\prime}-65^{\circ} 42^{\prime} \mathrm{W}\right.$; depth 113-159 m; $\mathrm{n}=7$; body length 70-93 cm; March 2009) and $M$. hubbsi from San Matías Gulf, Argentina (Atlantic Ocean) $\left(41^{\circ} 40^{\prime}-42^{\circ} 10^{\prime} \mathrm{S} ; 63^{\circ} 50^{\prime}-65^{\circ} 00^{\prime} \mathrm{W} ; \mathrm{n}=21\right.$; depth not recorded; body length $28-40 \mathrm{~cm}$; November 2007) and Patagonian shelf of Argentina (Atlantic Ocean) $\left(50^{\circ} 10^{\prime}-52^{\circ} 17^{\prime} \mathrm{S} ; 63^{\circ} 49^{\prime}-67^{\circ} 38^{\prime} \mathrm{W}\right.$; depth 70-157 m; n= 8; body length 43-62 cm; March 2009).

Worms found in the intestine were isolated and fixed in a hot $4 \%$ formaldehyde solution and subsequently stored in $70 \%$ ethanol. Entire tapeworms were stained with Langeron's alcoholic chlorhydric carmine (Langeron 1949), differentiated in acid ethanol, dehydrated through a gradual ethanol series, cleared in beechwood creosote and mounted in Canada balsam. Details of the internal anatomy were determined from thick, serial handcut transverse sections of proglottides stained with Langeron's alcoholic chlorhydric carmine. In the first species described below, intrauterine eggs were studied from whole mounts and in the second one spontaneously laid eggs were fixed in a hot $4 \%$ formaldehyde solution and examined in distilled water for drawing. Eggs prepared for scanning electron microscopy (SEM) could not be studied because they were shrivelled.

Specimens from Argentina were deposited in the Parasitological Collection of the Museo Argentino de Ciencias Naturales "Bernardino Rivadavia", Buenos Aires, Argentina (MACN-Pa); the Institute of Parasitology, České Budějovice, Czech Republic (IPCAS); and the Museum für Naturkunde, Zentralinstitut der Humboldt-Universität, Berlin, Germany (ZMB). The following material was also studied: type material (TM) of Clestobothrium crassiceps from M. merluccius (preserved in $75 \%$ ethanol) deposited in ZMB (syntype "Vermes" E-1807), which was stained and transversely sectioned as described above; voucher material (VM) of C. crassiceps from M. merluccius deposited in the Natural History Museum, London, United Kingdom (BMNH 1976.4.12.152-154, 1986.5.21.71-73, 1989.1.31.21-26, 1989.7.6.17, 1989.7.6.31) from north-eastern Atlantic, and Clestobothrium sp. from Merluccius sp. (BMNH 1989.1.5.25-30) off the Malvinas Islands.

Five tapeworms from $M$. hubbsi and one from M. australis were prepared for SEM as follows: post-fixed in 1\% osmium tetroxide, dried with hexamethyldisilazane (Riedel-De Haën ${ }^{\circledR}$ ), mounted on stubs with adhesive tape, sputter coated with gold in a Thermo VG Scientific Polaron SC 7630 and examined with a Philips XL 30 scanning electron microscope.

The type and distribution of microtriches were studied on the scolex and proglottides. Measurements of the microtriches were made from micrographs. Microthrix terminology follows Chervy (2009).

Measurements include the range followed by the mean in parentheses and total number of observations (n). For two-dimensional measurements, length is given before width. All measurements are given in micrometres, unless otherwise stated. Illustrations were made with the aid of a camera lucida attached to a Zeiss Axioskop microscope equipped with differential interference contrast optics. The names of type hosts are used according to FishBase (Froese and Pauly 2010).

\section{RESULTS}

Clestobothrium splendidum sp. $\mathrm{n}$.

Figs. 1-4

Description (based on 2 tapeworms as whole mounts and transverse sections of pieces of strobila, and one observed with SEM): Bothriocephalidea, Bothriocephalidae. Medium-sized worms, flattened dorsoventrally, 89-105 mm ( $=2)$ in total length and 1,740-2,080 wide. Strobila markedly craspedote, anapolytic, consisting of 410-528 $(n=2)$ proglottides. All proglottides wider than long, with velum-like posterior margin. Internal proglottization coincides with external segmentation, secondary segmentation (spurious articulation, sensu Cooper 1918) present but uncommon, in mature and gravid proglottides (Figs. 1A, 2C, 4A, F).

Scolex globular to oval, projecting posteriorly over first proglottis $870-1,140 \times 608-1,000(\mathrm{n}=3)$ (Figs. 2A, $3 \mathrm{E})$. Scolex divided by longitudinal grooves into 2 dorsoventral hemispheres (Fig. 3A). Apical disk weekly developed forming 2 lip-like structures $350 \times 125(\mathrm{n}=2)$ perpendicular to longitudinal grooves and ending on anterior aperture of bothria (Fig. 3A, E). Scolex with tumuli (dome-shaped evaginations) (Boyce 1975) on all surfaces, more abundant on central surface between lips, lateral surface near longitudinal grooves (Fig. 3B), and surrounding aperture of bothria. Central surface between lips covered with long capilliform filitriches (not measured due to curled position) (Fig. 3C), marginal surface of lip covered with gladiate spinitriches 1.40-1.80 (1.60) $\times 0.25-0.30(0.28)(n=6)($ Fig. 3D). Lateral surface of scolex proximal to lips covered with scarce long capilliform filitriches (not measured due to curled position) interspersed with gladiate spinitriches 1.50-1.80 (1.70) $\times 0.23-0.33(0.27)(n=5)($ Fig. 3F). Lateral surface near longitudinal grooves covered with gladiate spinitriches 2-2.50 (2.40) × 0.20-0.35 (0.30) $(\mathrm{n}=5)$, (Fig. 3B, H) . Bothria large, prominent, spherical to oval $600-700 \times 700$ $(\mathrm{n}=2)$, deep in lateral view; aperture of bothria small, delimited by U-shaped sphincter with well-developed musculature and connected anteriorly by a narrow muscle (tendon sensu Rees 1958) (Figs. 1A, 2A). Surface around aperture of bothria covered with scarce long capilliform filitriches (not measured due to curled position) interspersed with gladiate spinitriches 2.60-3.55 (3) $\times$ 0.25-0.43 (0.30) $(\mathrm{n}=5)$ (Fig. 3G). Posterior projection of scolex covered with scarce capilliform filitriches (not measured due to curled position) interspersed with gladiate spinitriches $1.80-2.40(2.00) \times 0.20-0.32(0.26)$ $(n=6)$ (Fig. 3I). Neck absent, first proglottides immediately adjacent to posterior projection of scolex.

Internal longitudinal musculature strongly developed, formed by large bundle of muscle fibres. Nerve cord conspicuous, situated lateral on each side of proglottis. Osmoregulatory canals medullary, 3 pairs on each side of proglottis, 1 larger pair separating fields of testes from other genital organs $20-30$ in diameter, 1 pair between 
A
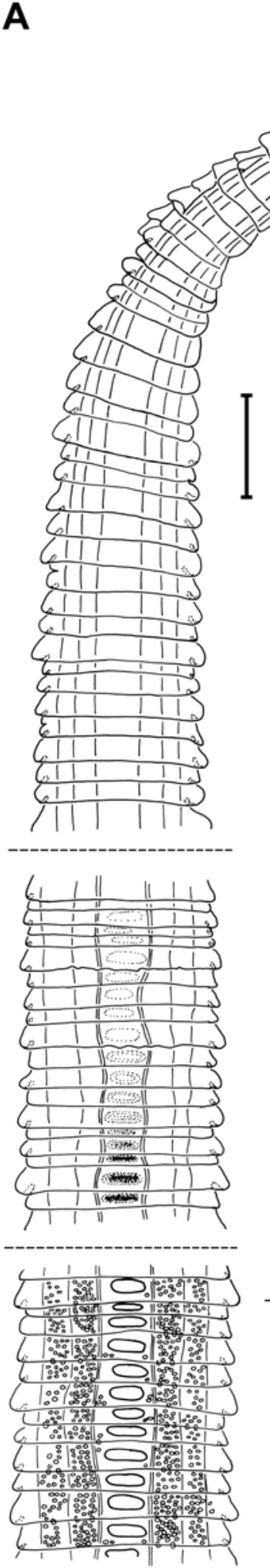
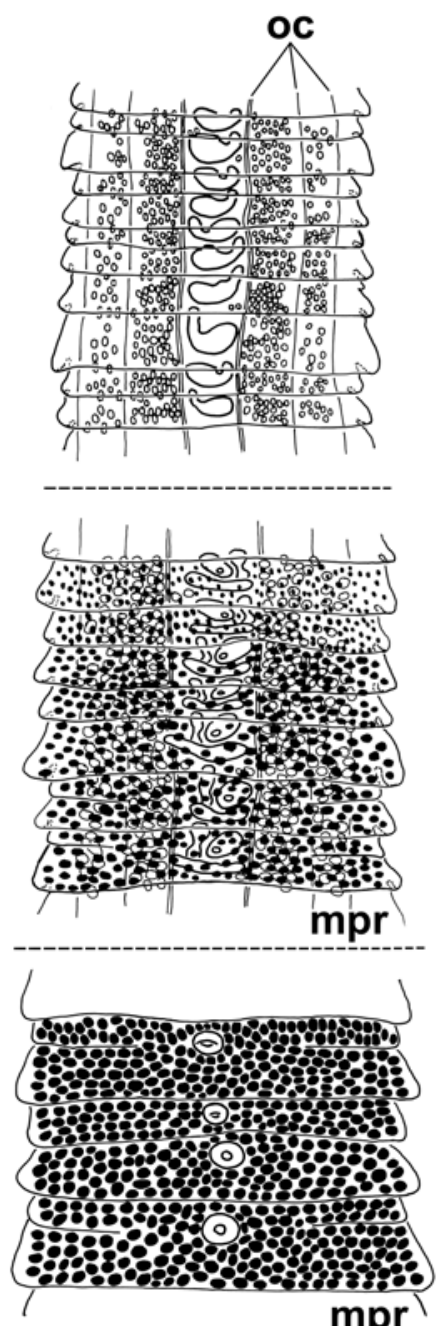

mpr

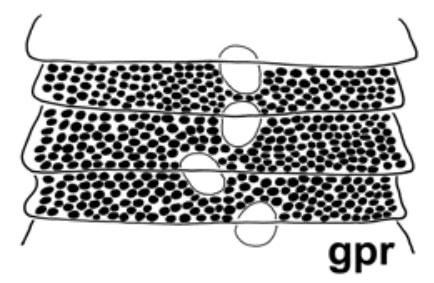

B
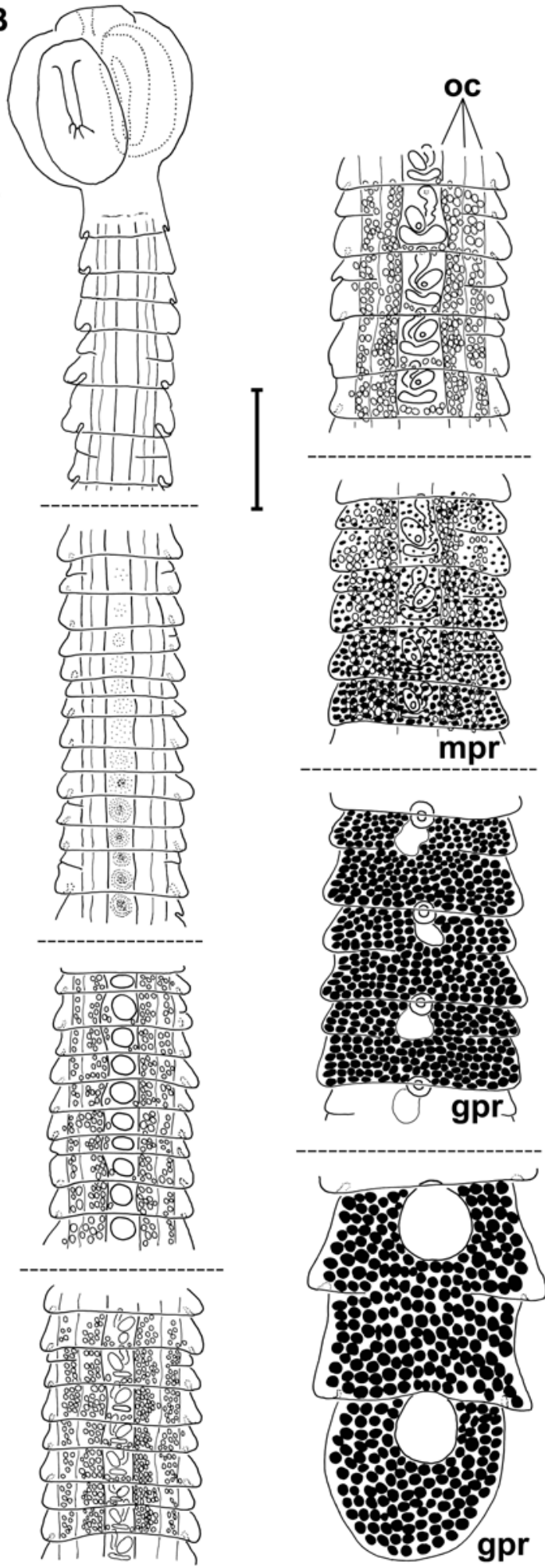

Fig. 1. Clestobothrium, new species, pieces of strobila from entire worms. A-Clestobothrium splendidum sp. n., holotype (MACNPa No. 512/1A-C) from Merluccius australis showing osmoregulatory canals, irregularly alternating cirrus-sac and vitelline follicles in dorsal view; last piece of strobila showing uterine sac in ventral view; B - Clestobothrium cristinae sp. n., paratype (IPCAS C-601) from Merluccius hubbsi showing osmoregulatory canals, irregularly alternating cirrus-sac and vitelline follicles in dorsal view; two last pieces of strobila showing uterine sac in ventral view. Abbreviations: gpr - gravid proglottides; mpr - mature proglottides; msp - muscular sphincter; $\mathrm{nm}$ - narrow muscle; oc - osmoregulatory canals. Scale bars $=500 \mu \mathrm{m}$. 
wide internal field and narrow external field of testes 15-25 in diameter and 1 smaller pair external to fields of testes 5 in diameter in transverse sections (Fig. 2D, E).

Immature proglottides 120-220 (170) × 560-1,260 (970) $(\mathrm{n}=10)$, length/width ratio 1:0.12-0.22 (1:0.17) $(\mathrm{n}=10)$, anterior and middle surfaces covered with capilliform filitriches $1.10-1.30(1.20) \times 0.10-0.14(0.12)$ $(n=4)$ (Fig. 4B); first part of posterior surface with transitional area of capilliform filitriches $0.85-0.96(0.90) \times$ $0.10(\mathrm{n}=4)$ interspersed with scarce gladiate spinitriches $1.16-1.56(1.37) \times 0.30-0.45(0.40)(n=4)$; subsequently, capilliform filitriches interspersed with abundant gladiate spinitriches $2.40-3.35(2.95) \times 0.40-0.50(0.45)$ $(\mathrm{n}=4)$ (Fig. 4A, C, E), lateral border covered with longest gladiate spinitriches $2.75-3.50(3.20) \times 0.33-0.46$ $(0.40)(n=5)$ (Fig. 4D). Tumuli distributed from middle to posterior surfaces of immature proglottis (Fig. 4E). Mature proglottides $230-420(520) \times 1,340-1,710(1,600)$ $(\mathrm{n}=10)$, length/width ratio 1:0.16-0.27 (1:0.20) $(\mathrm{n}=10)$. Gravid proglottides $260-420(350) \times 1,530-1,820(1,650)$ $(\mathrm{n}=7)$, length/width ratio $1: 0.17-0.26(1: 0.22)(\mathrm{n}=7)$ (Fig. 4F).

Testes medullary, spherical to slightly oval 40-100 (67) $(\mathrm{n}=10)$ in diameter; 49-90 (65) $(\mathrm{n}=10)$ per mature proglottis, distributed in 1 layer occupying 2 lateral fields, each one divided into one wide internal field and one narrow external field. Testes usually continuous from proglottis to proglottis, few testes located posterior to ovary in some proglottides (Figs. 1A, 2C-E). Genital pore dorsal, sub-median, transversely elongate, anterior to spurious articulations when present, situated $20-40 \%$ $(29 \%)(n=6)$ from anterior margin of mature proglottis; genital atrium present (Figs. 2B, 4F, G). Cirrus-sac globular, small, thick-walled, irregularly alternating dextrally or sinistrally to median line in successive proglottides, $85-100(93)(n=6)$ in diameter, occupying 4-7\% $(6 \%)$ $(n=6)$ of proglottis width in mature proglottides. Cirrus unarmed occupying $40-50 \%$ of cirrus-sac length. Seminal vesicle not observed. Vas deferens strongly coiled, situated anterolaterally (Fig. 2B, E).

Ovary medullary, equatorial, bilobed, slightly folliculate, transversely elongated or slightly curved towards anterior margin of proglottis, 90-130 (122) × 300-430 (380) $(\mathrm{n}=10)$ occupying $21-26 \%(24 \%)(\mathrm{n}=10)$ of proglottis width in mature proglottides; isthmus conspicuous. Vaginal canal situated in midline of proglottis between ovary lobes, vaginal sphincter present (Fig. 2B, C). Seminal receptacle not observed. Vitelline follicles densely distributed in one circumcortical layer, forming continuous field around margins of proglottis in transverse section and from proglottis to proglottis; interrupted dorsally at level of genital pore and ventrally at level of uterus when gravid. Follicles spherical to oval 25-50 (36) $(n=14)$ in diameter in mature proglottides (Figs. 1A, 2B-E). Vitelline reservoir dorsal, usually visible in gravid proglottides, overlaps ovary isthmus (Fig. 2B). Uterus tubular, almost straight, irregularly alternating dextrally or sinistrally to midline; enlarged in gravid proglottides, forming a uterine-sac occupying $13-20 \%(15 \%)(n=6)$ of gravid proglottis width, sometimes extends to preceding proglottis. Uterine pore ventral, median or slightly submedian, at anterior margin of proglottis, generally overlapped by velum-like posterior margin of preceding proglottis in mature proglottides (Figs. 1A, 2C-E). Intrauterine eggs oval 55-65 × 35-45 $(n=6)$, unembryonated, with inconspicuous operculum.

Type host: Merluccius australis (Hutton) (Gadiformes: Merlucciidae); vernacular names "merluza austral" in Argentina, "Southern hake" or "Patagonian hake" in the United Kingdom.

Type 1 ocality: Patagonian shelf $\left(52^{\circ} 54^{\prime} \mathrm{S} ; 64^{\circ} 36^{\prime} \mathrm{W}\right)$, Atlantic Ocean, Argentina.

Type materia 1: Holotype MACN-Pa No. 512/1A-C, paratype IPCAS C-600 (each entire worm mounted on 3 slides with transverse sections of proglottides).

Site of infection: Intestine.

Infection indices : Prevalence: $29 \%$ (2/7); intensity: $1-2$ worms per fish.

Ety mology: The species name means "splendid".

Remarks. The new species belongs to Clestobothrium within the Bothriocephalidea as defined by Bray et al. (1994) and Kuchta et al. (2008). The characteristic shape of scolex (globular to oval), presence of a weakly developed apical disk forming two lip-like structures and a strongly U-shaped muscular sphincter connected anteriorly by a narrow muscle around the aperture of bothria are important features for assigning a species to Clestobothrium.

The VM from the northern Atlantic and one syntype (TM) from the Mediterranean Sea near Naples, both parasitizing M. merluccius (L.), were studied. Most of the VM are contracted and/or overstained, and the TM is an incomplete, gravid worm with scolex. Moreover, the latter was poorly stained with carmine because it had remained in fixative for about 200 years. However, it was possible to observe some morphological characteristics and to take measurements.

The VM are 23-76 $\mathrm{mm}(\mathrm{n}=9)$ in total length $(\mathrm{TM}=24 \mathrm{~mm})$; possess a craspedote strobila with 142 201 proglottides (TM $=102$ proglottides), all of which are wider than long, with spurious articulations in mature and gravid proglottides. Each proglottis has a velum-like posterior margin covered with large gladiate spinitriches (TM shows secondary segmentation but lacks spurious articulations) (Fig. 7B, D). The internal longitudinal musculature is formed by a conspicuous bundle of fibres. The osmoregulatory canals are medullary, with two pairs on each side of the proglottis (one pair separating the fields of testes from other genital organs and one pair located between a wide internal field and a narrow external field of testes) (this same distribution pattern is found in TM) (Fig. 7B, D, E). The immature proglottides are 50-100 

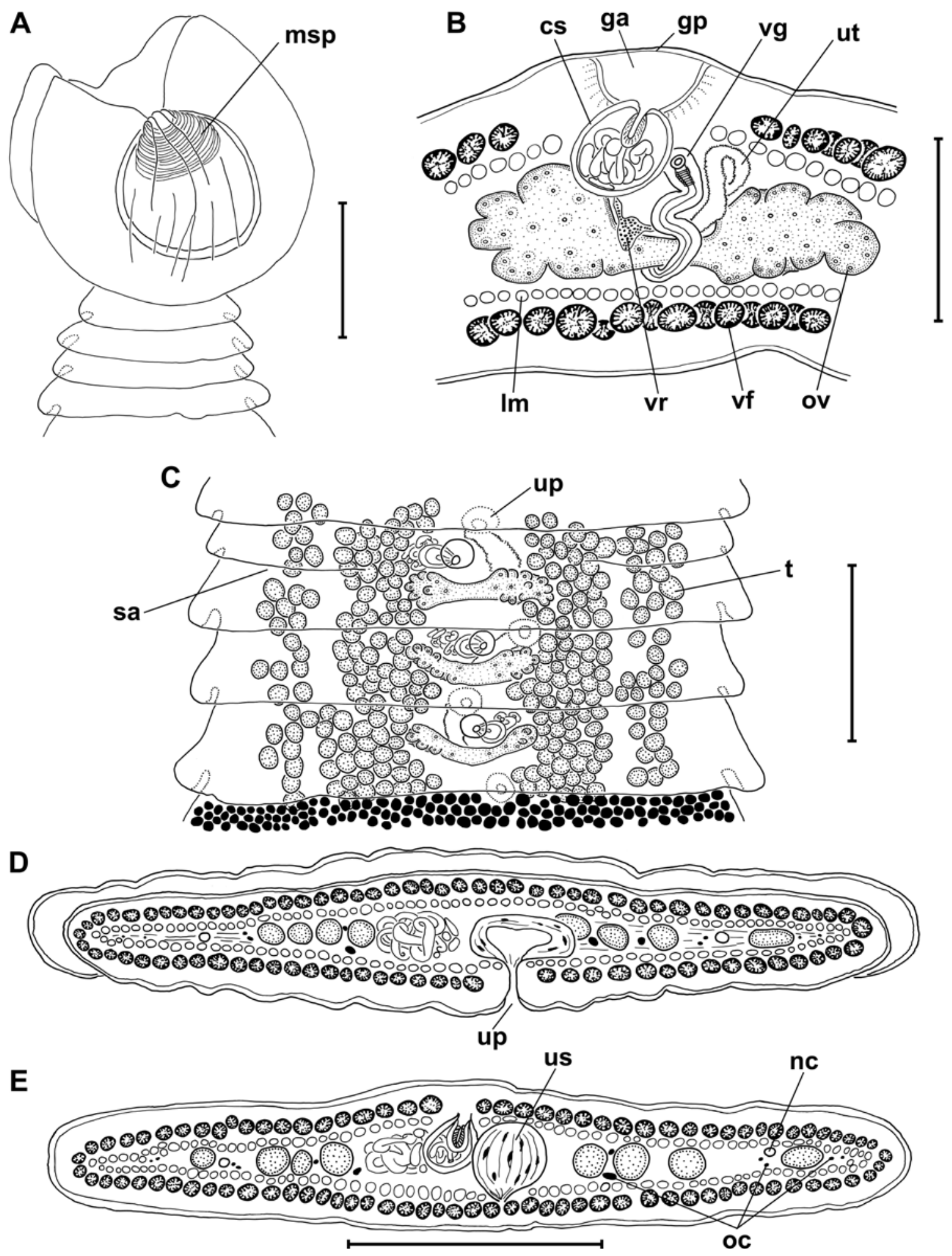

Fig. 2. Clestobothrium splendidum sp. n. from Merluccius australis. A - scolex showing musculature of bothria; dorsoventral view, paratype (IPCAS C-600); note broken apex; B - partial transverse cross-section at level of genital pore; holotype (MACN-Pa No. 512/1A-C); C - mature proglottides; vitelline follicles only illustrated in posterior proglottis; osmoregulatory canals not illustrated; dorsal view, paratype (IPCAS C-600); D - transverse cross-section of mature proglottis at level of uterine pore; paratype (IPCAS C-600); $\mathbf{E}$ - transverse cross-section of mature proglottis at level of cirrus-sac and uterine sac; paratype (IPCAS C-600). Abbreviations: cs - cirrus-sac; ga - genital atrium; gp - genital pore; $1 \mathrm{~m}$ - bundles of longitudinal musculature; msp - muscular sphincter; $\mathrm{nc}$ - nerve cord; oc - osmoregulatory canals; ov - ovary; sa - spurious articulation; $\mathrm{t}$ - testes; up - uterine pore; us - uterine sac; ut - uterus; vf - vitelline follicles; vg - vagina; vr - vitelline reservoir. Scale bars: A $=250 \mu \mathrm{m} ; \mathrm{B}=200 \mu \mathrm{m} ; \mathrm{C}-\mathrm{E}=500 \mu \mathrm{m}$. 

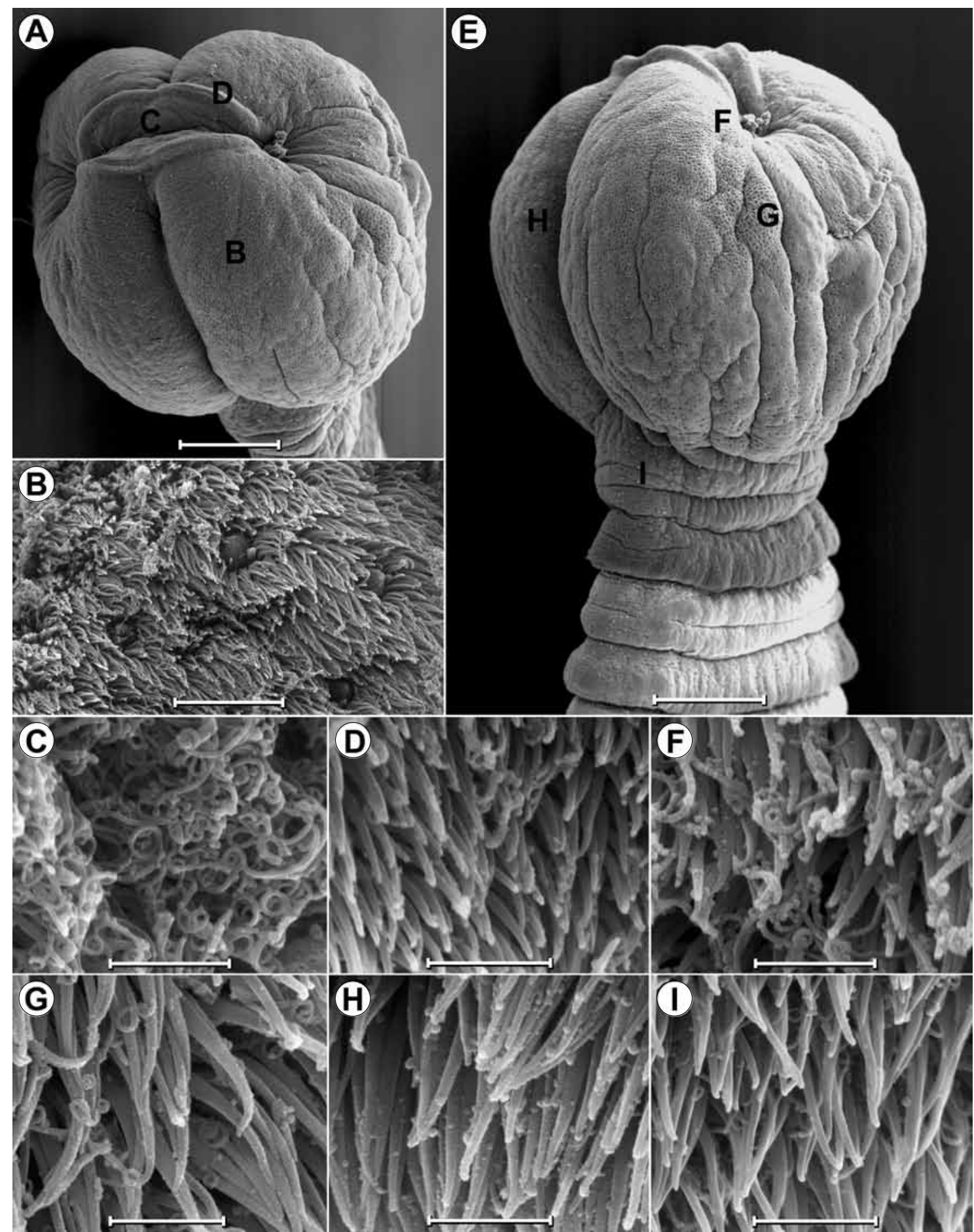

Fig. 3. Clestobothrium splendidum sp. n. from Merluccius australis, scanning electron micrographs. A-apical view of scolex showing two lip-like structures; letters B-D indicate surfaces shown at high magnification in B-D; B - lateral surface of bothria showing tumuli; $\mathbf{C}$ - central surface between lips; D - marginal surface of lips; $\mathbf{E}$ - dorsoventral view of scolex projecting over first immature proglottides; letters F-I indicate surfaces shown at high magnification in F-I; F - lateral surface of scolex proximal to lips; $\mathbf{G}$ - surface around aperture of bothria; $\mathbf{H}$ - lateral surface near longitudinal grooves; $\mathbf{I}$ - surface of posterior projection of scolex. Scale bars: $\mathrm{A}, \mathrm{E}=200 \mu \mathrm{m} ; \mathrm{B}=10 \mu \mathrm{m} ; \mathrm{C}, \mathrm{D}, \mathrm{F}-\mathrm{I}=2 \mu \mathrm{m}$.

$\times 600-1,100(\mathrm{TM}=120-230 \times 500-870)$, the mature proglottides are $120-500 \times 600-1,150(\mathrm{TM}=150-220$ $\times 950-1,100)$ and the gravid proglottides are $210-980 \times$
$820-2,020(\mathrm{TM}=310-500 \times 950-1,120)$. The scolex is globular in shape, $600-1,260(\mathrm{TM}=1,300) \times 660-1,300$ ( $\mathrm{TM}=1,200$ wide in lateral view), with a weakly devel- 


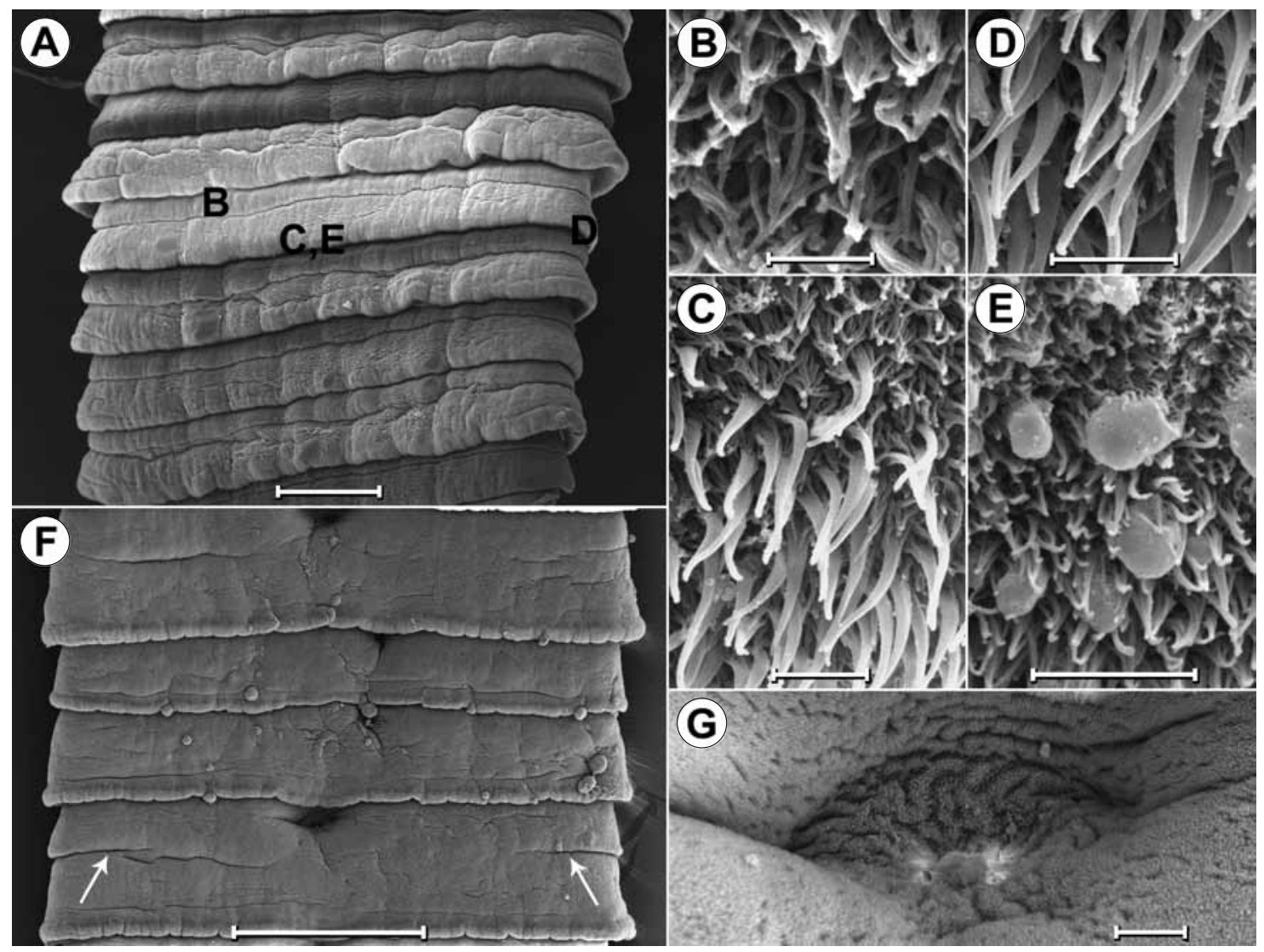

Fig. 4. Clestobothrium splendidum sp. n. from Merluccius australis, scanning electron micrographs. A - piece of immature strobila; letters B-E indicate surfaces shown at high magnification in B-E; B - anterior surface of proglottis; $\mathbf{C}$ - surface from middle to posterior (transitional) part of proglottis; D - lateral surface of posterior border of proglottis; $\mathbf{E}$ - surface from middle to posterior (transitional) part of proglottis showing tumuli; $\mathbf{F}$ - piece of mature strobila showing spurious articulation (white arrows); dorsal view; $\mathbf{G}$ - genital pore. Scale bars: $\mathrm{A}=200 \mu \mathrm{m} ; \mathrm{B}=1 \mu \mathrm{m} ; \mathrm{C}, \mathrm{D}=2 \mu \mathrm{m} ; \mathrm{E}=5 \mu \mathrm{m} ; \mathrm{F}=500 \mu \mathrm{m} ; \mathrm{G}=20 \mu \mathrm{m}$.

oped apical disk forming two lip-like structures in the apical region; the bothria are 500-1,050 $(\mathrm{TM}=800) \times 450$ 980, with a U-shaped muscular sphincter and an anterior narrow muscle connects the musculature of the sphincter (Fig. 7A, C). The testes are medullary and distributed in two lateral fields, each one divided into one wide internal field and one narrow external field and continuous between the proglottides (in TM, both fields on each side of the proglottis are of similar width), 35-56 (TM = 36-52) in total number and $35-80(\mathrm{TM}=50-60)$ in diameter; they do not surround the ovary posteriorly (Fig. 7B, D, E). The dorsal genital pore is rounded, at the same level of the spurious articulations, situated $40-56 \%$ from the anterior margin of the mature proglottis $(\mathrm{TM}=30-44 \%)$; the genital atrium is not observed; the cirrus-sac is irregularly alternating dextrally or sinistrally to the median line of proglottis, measures 108-127 × 80-94 $(\mathrm{TM}=100$ $\times 75)$ and occupies $11-15 \%(13 \%)$ of proglottis width $(\mathrm{TM}=11 \%)$. The ovary is medullary and situated posteriorly, bilobed and strongly folliculate, with the lobes markedly extending towards the anterior part of the proglottis; it measures $120-500 \times 640-1,140$ and occupies $21-26 \%$ of proglottis width (Fig. 7B) (not observed in TM). The vaginal sphincter and seminal receptacle were not observed. The vitelline follicles are circumcortical and distributed in a single layer forming a continuous field from proglottis to proglottis; the follicles are 30-50 in diameter $(\mathrm{TM}=25-35)$ (Fig. 7B, D, E). The uterus is tubular, usually sinuous with the uterine-sac occupying $38-83 \%$ of proglottis width $(\mathrm{TM}=25-35 \%)$ and extending towards the anterior part of the proglottis (Fig. 7B). The uterine pore is ventral and situated near the anterior margin of the proglottis (Fig. 7B). The intrauterine eggs have an operculum $(\mathrm{TM}=55-63 \times 32-35)$.

Clestobothrium splendidum is characterised by the following combination of features: all the proglottides being much wider than long; presence of two types of microtriches (capilliform filitriches and gladiate spinitriches) on the tegument surface; a genital pore situated at $20-40 \%$ from the anterior margin of mature proglottides; 49-90 testes, few of them located posterior to ovary in some proglottides; a small globular cirrus-sac occupying $4-7 \%$ of the mature proglottis width; a transversely elongated genital pore with a genital atrium; three pairs of osmoregulatory canals on each side of the proglottis; an equatorial, bilobed, slightly folliculate ovary, elongated 
transversely or curved slightly towards the anterior margin of the proglottis; a vagina with sphincter and unembryonated eggs with inconspicuous operculum.

Clestobothrium is currently composed of three species, the type species C. crassiceps, $C$. gibsoni Dronen et Blend, 2005, and C. neglectum (Lönnberg, 1893). Clestobothrium splendidum can be distinguished from all these species by the presence of a vaginal sphincter, a genital atrium and three pairs of osmoregulatory canals on each side of the proglottis (vs. two pairs). Additionally, the new species differs from $C$. neglectum in lacking a scalloped pattern of longitudinal ridges across the dorsal and ventral surfaces of the proglottides, the shape and size of the testes (spherical 40-100 vs. oval 32-50 × 20-33) and the shape of the cirrus-sac (globular vs. elongate); from $C$. crassiceps in the location and shape of the ovary (equatorial, slightly folliculate, transversely elongated or slightly curved towards anterior margin of proglottis vs. posterior, strongly folliculate and markedly extended towards the anterior part of the proglottis), and the presence of some testes posterior to the ovary (vs. absence of testes posterior to the ovary); and from $C$. gibsoni in the distribution of vitelline follicles (one layer vs. 2-3 layers as shown by Dronen and Blend 2005, fig. 5), distribution of testes (two lateral fields, each of which is divided into two fields vs. two undivided lateral fields) and presence of testes posterior to the ovary (vs. absence of testes posterior to the ovary).

Clestobothrium splendidum, which is the first species of the genus completely studied by SEM, has two types of microtriches, capilliform filitriches and gladiate spinitriches, distributed on the surface of the scolex and proglottides as indicated above. Cooper (1918), who exhaustively studied C. crassiceps from M. bilinearis (Mitchill), mentioned the presence of "cirri" all over the scolex surface, and a band of "stout spinelets" on the posterior border of the proglottides. Dronen and Blend (2003) observed the spinithrix type of microtriches on the posterior fourth of the scolex and proglottides of $C$. neglectum from Raniceps raninus (L.), but Dronen and Blend (2005) made no reference to microtriches for C. gibsoni from Bathygadus macrops Goode et Bean. The new bothriocephalidean shares with $C$. crassiceps and $C$. neglectum the possession of gladiate spinitriches (= spiniform-like microtriches) on the posterior surface of the scolex (including the posterior projection of the scolex) and larger gladiate spinitriches on the posterior surface of the proglottides.

The examination of the TM and VM of $C$. crassiceps from $M$. merluccius allowed to confirm morphological features described by other authors (e.g. Cooper 1918 for C. crassiceps from $M$. bilinearis), and also could suggest intraspecific size variation between worms from the North Atlantic Ocean and the Mediterranean Sea.

Dronen and Blend (2003) and the authors of the present paper studied the voucher specimens of a bothriocephalidean from M. merluccius (BMNH No. 1976.4.12.152-
154). These specimens have a U-shaped muscular sphincter connected anteriorly by a narrow muscle around the aperture of the bothria and a weekly developed apical disk forming two lip-like structures in the apex of the scolex, indicating that they belong to C. crassiceps (Fig. 7A) rather than to Bothriocephalus kivuensis Baer et Fain, 1958 (now B. acheilognathi Yamaguti, 1934; see Pool 1987, Kuchta and Scholz 2007), as suggested by Dronen and Blend (2003).

\section{Clestobothrium cristinae sp. n.}

Figs. 1, 5, 6

Description (based on 6 tapeworms as whole mounts and 6 observed with SEM): Bothriocephalidea, Bothriocephalidae. Small-sized worms, flattened dorsoventrally, up to $17-59 \mathrm{~mm}(28 \mathrm{~mm})$ in total length and $830-1,360$ $(1,050) \quad(n=12)$ wide. Strobila markedly craspedote, anapolytic, consisting of 71-219 (118) $(\mathrm{n}=12)$ proglottides. All proglottides wider than long, with velum-like posterior margin. Internal proglottization coincides with external segmentation, secondary segmentation (spurious articulation, sensu Cooper 1918) present in some mature and gravid proglottides (Figs. 1B, 5C, 6D, F, G).

Scolex globular to oval, projecting posteriorly over first proglottis, 435-1,050 (675) × 450-800 (560) $(\mathrm{n}=12)$. Scolex divided by longitudinal grooves into 2 dorsoventral hemispheres. Apical disk weekly developed forming 2 lip-like structures perpendicular to longitudinal grooves and ending on anterior aperture of bothria 220-230 $\times$ 130-150 $(\mathrm{n}=2)$ (Figs. 5A, B, 6A). Scolex with tumuli (dome-shaped evaginations) (Boyce 1976) on all surfaces, more abundant on central surface between lips, lateral surface near longitudinal grooves, and surrounding aperture of bothria (Fig. 6A). Central surface between lips covered with long capilliform filitriches (not measured due to curled position) interspersed with small gladiate spinitriches $0.90-1.20(1.00) \times 0.25-0.35(0.30)(\mathrm{n}=5)$ (Fig. 6B); marginal surface of lip covered with gladiate spinitriches 2.20-2.70 $(2.50) \times 0.35-0.45(0.38)(\mathrm{n}=6)$ (Fig. 6C). Lateral surface near longitudinal grooves covered with gladiate spinitriches 2.60-3.30 (2.90) $\times 0.25$ $0.35(0.30)(\mathrm{n}=6)$. Bothria large, prominent, spherical to oval 420-650 (540) $(\mathrm{n}=10) \times 320-550(402)(\mathrm{n}=8)$, deep in lateral view, apertures of bothria small, delimited by U-shaped sphincter with well-developed musculature connected anteriorly by a narrow muscle (tendon sensu Rees 1958) (Figs. 5A, 6A). Bothria aperture elongated when fully relaxed (Fig. 5B). Surface around aperture of bothria covered with capilliform filitriches 1.60-1.90 $\times$ $1.15(\mathrm{n}=2)$, interspersed with gladiate spinitriches 2.50 $2.70 \times 0.25-0.30(n=2)$. Posterior projection of scolex covered with scarce capilliform filitriches (not measured due to curled position) interspersed with long gladiate spinitriches 2.60-3.60 (3.00) × 0.40-0.60 (0.50) $(\mathrm{n}=6)$. Neck absent, first proglottides immediately adjacent to posterior projection of scolex (Fig. 6A). 
A

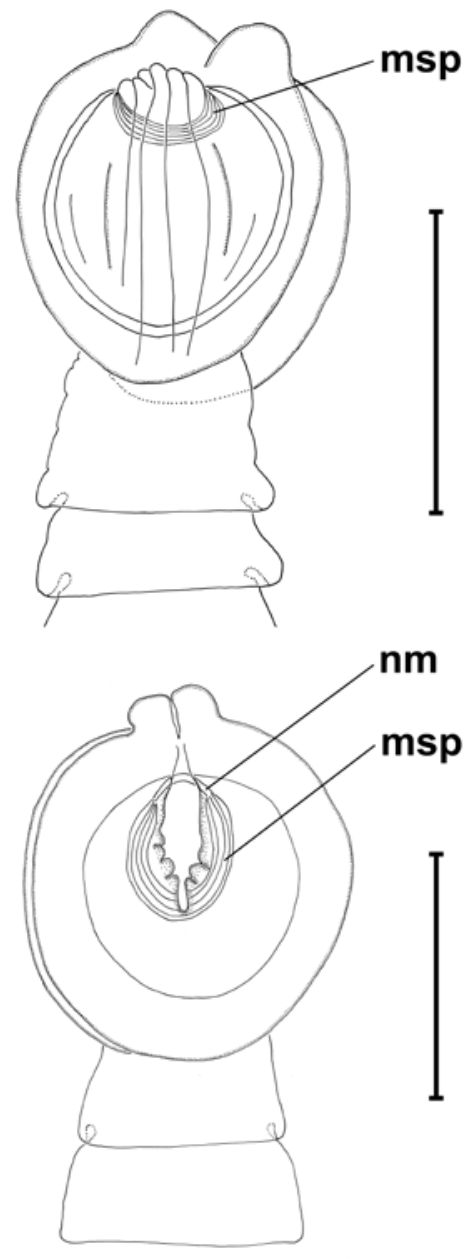

C

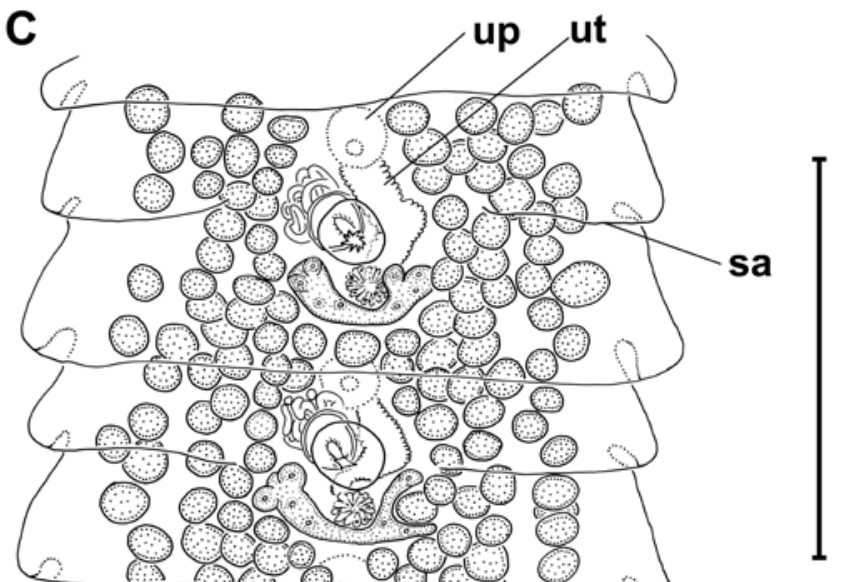

E

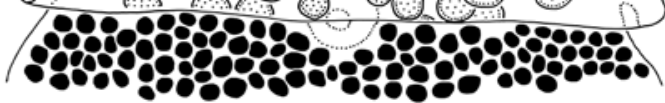

D

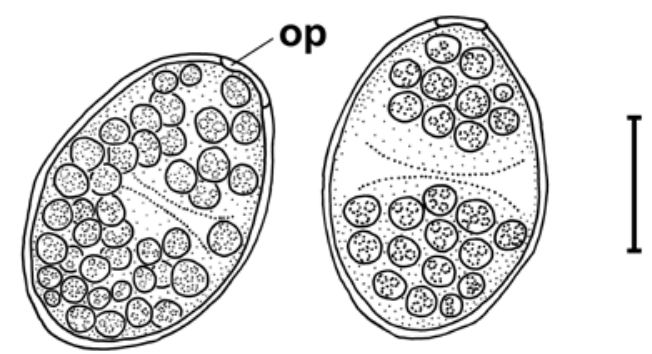

cs
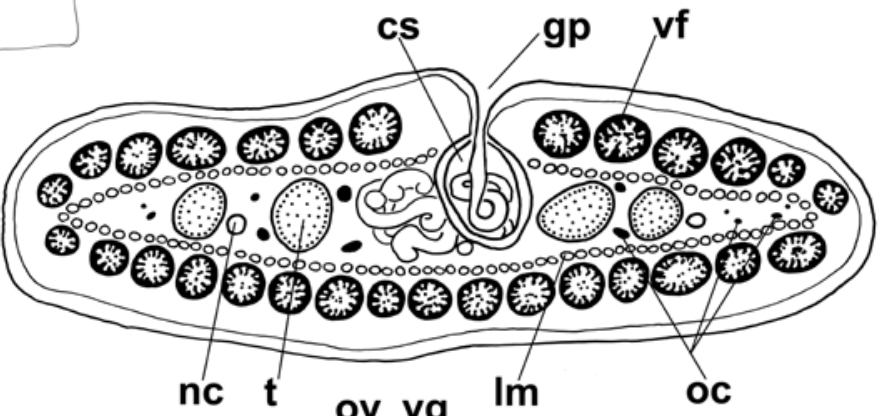

$\mathbf{F}$

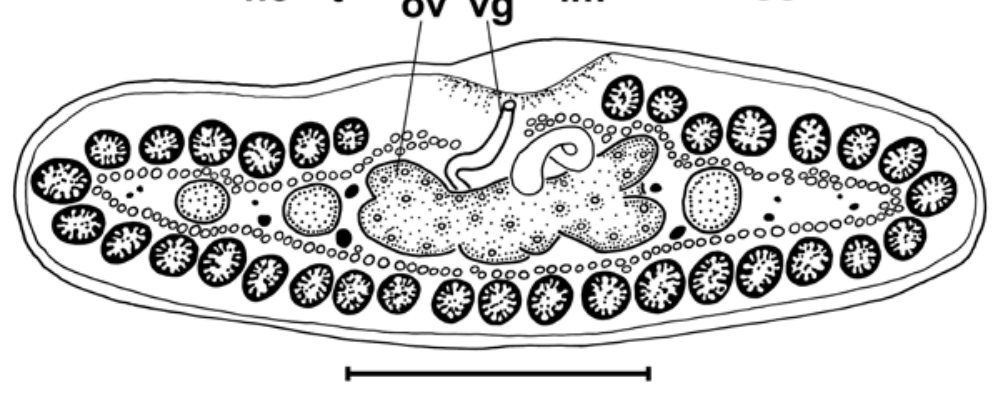

Fig. 5. Clestobothrium cristinae sp. n. from Merluccius hubbsi. A-scolex showing contracted U-shaped muscular sphincter; dorsoventral view, holotype (MACN-Pa 511/1); B - scolex relaxed showing musculature of bothria; dorsoventral view, paratype (MACNPa 511/2); C - mature proglottides; vitelline follicles only illustrated in posterior proglottis; osmoregulatory canals not illustrated; dorsal view, holotype (MACN-Pa 511/1); D - eggs with operculum; $\mathbf{E}$ - transverse cross-section of mature proglottis at level of genital pore; paratype (MACN-Pa 511/2); F - transverse cross-section of mature proglottis at level of ovary; paratype (MACN-Pa 511/2). Abbreviations: cs - cirrus-sac; gp - genital pore; $1 \mathrm{~m}$ - bundles of longitudinal musculature; msp - muscular sphincter; nc - nerve cord; $\mathrm{nm}$ - narrow muscle; oc - osmoregulatory canals; op - operculum; ov - ovary; sa - spurious articulation; $\mathrm{t}$ - testes; up - uterine pore; ut - uterus; vf - vitelline follicles; vg - vagina. Scale bars: A-D = $500 \mu \mathrm{m} ; \mathrm{E}, \mathrm{F}=250 \mu \mathrm{m}$. 


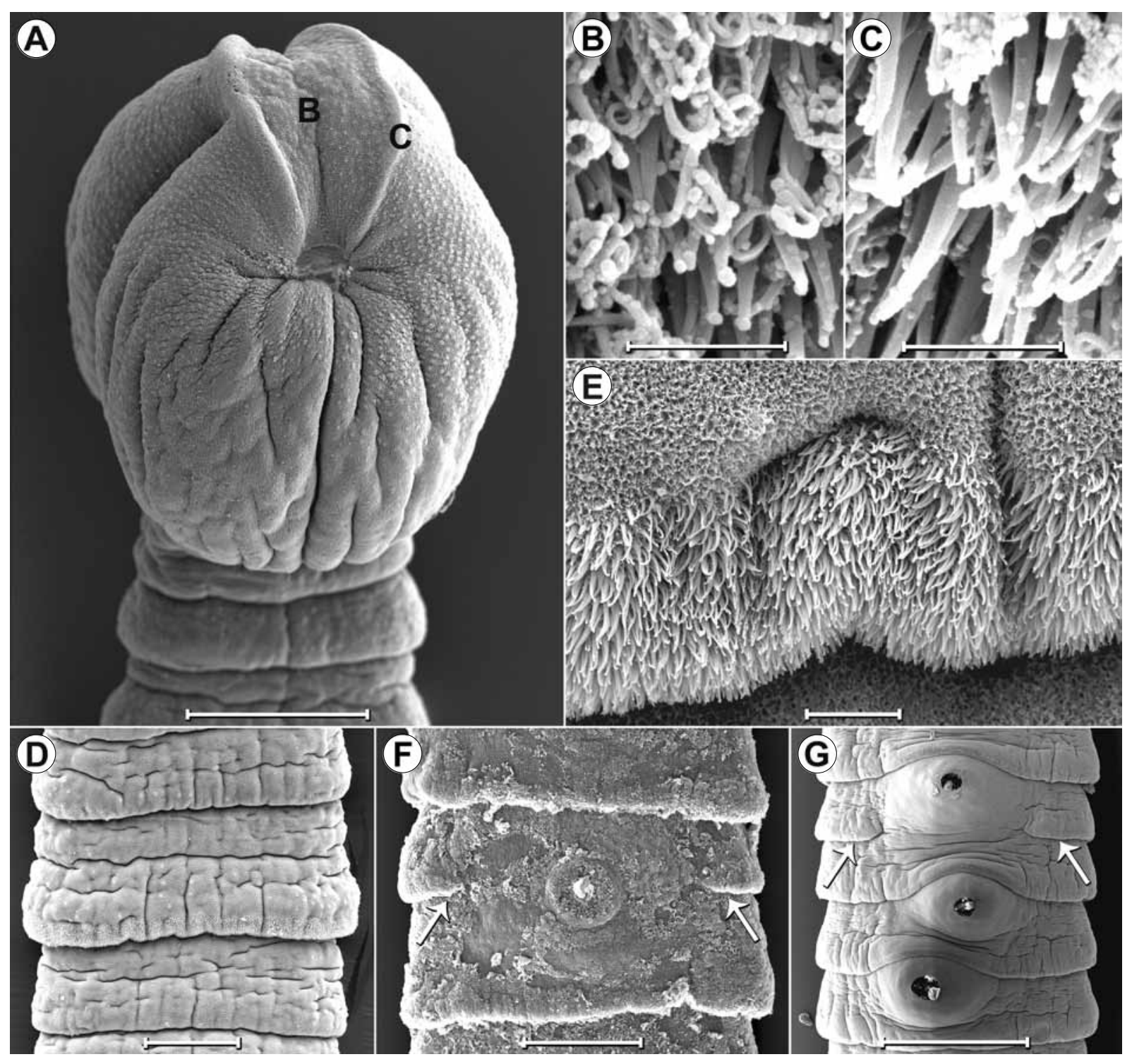

Fig. 6. Clestobothrium cristinae sp. n. from Merluccius hubbsi, scanning electron micrographs. A - dorsoventral view of scolex showing tumuli; letters B, C indicate surfaces shown at high magnification in B, C; B - central surface between lips; $\mathbf{C}-$ marginal surface of lips; D - piece of immature strobila; $\mathbf{E}$ - surface of middle and posterior part of immature proglottis; $\mathbf{F}$ - piece of mature strobila showing position of genital pore relative to spurious articulation (white arrows), dorsal view; $\mathbf{G}-$ piece of gravid strobila showing uterine pore, eggs and spurious articulation (white arrows); ventral view. Scale bars: $\mathrm{A}=200 \mu \mathrm{m} ; \mathrm{B}, \mathrm{C}=2 \mu \mathrm{m}$; $\mathrm{D}=100 \mu \mathrm{m} ; \mathrm{E}=10 \mu \mathrm{m} ; \mathrm{F}, \mathrm{G}=500 \mu \mathrm{m}$.

Internal longitudinal musculature well developed, formed by bundle of muscle fibres. Nerve cord conspicuous, situated lateral on each side of proglottis. Osmoregulatory canals medullary, 3 pairs on each side of proglottis, 1 larger pair separating fields of testes from other genital organs $15-30$ in diameter, 1 pair between wide internal field and narrow external field of testes 10-15 in diameter and 1 smaller pair external to fields of testes, $5-15$ in diameter in transverse sections (Fig. 5E, F).

Immature proglottides 80-300 (160) $\times$ 380-810 (536) $(\mathrm{n}=40)$ length/width ratio 1:0.15-0.55 $(0.30)(\mathrm{n}=40)$, anterior and middle surfaces covered with capilliform filitriches $0.85-1.10(1.00) \times 0.10-0.14(0.10)(\mathrm{n}=5)$, first part of posterior surface with transitional area of capilliform filitriches (of same size as on anterior and middle surfaces) interspersed with scarce gladiate spinitriches $1.30-1.90(1.60) \times 0.40-0.60(0.50)(\mathrm{n}=4)$; subsequently, capilliform filitriches interspersed with abundant gladiate spinitriches 2.65-3.00 $(2.90) \times 0.40-0.60(0.50)(\mathrm{n}=4)$ (Fig. 6E), lateral border covered with gladiate spinitriches 2.70-3.40 (3.00) × 0.35-0.50 (0.45) $(\mathrm{n}=6)$. Tumuli not observed on surface of proglottides. Mature proglottides 175-500 (309) × 610-1,030 (837) $(\mathrm{n}=41)$, length/width ratio 1:0.20-060 $(0.40)(\mathrm{n}=41)$. Gravid proglottides 285-920 $(550) \times 790-1,290(1,007)(\mathrm{n}=39)$, length/width ratio 1:0.30-0.95 (0.55) $(n=39)$ (Figs. 1B, 5C, 6D, F, G). 

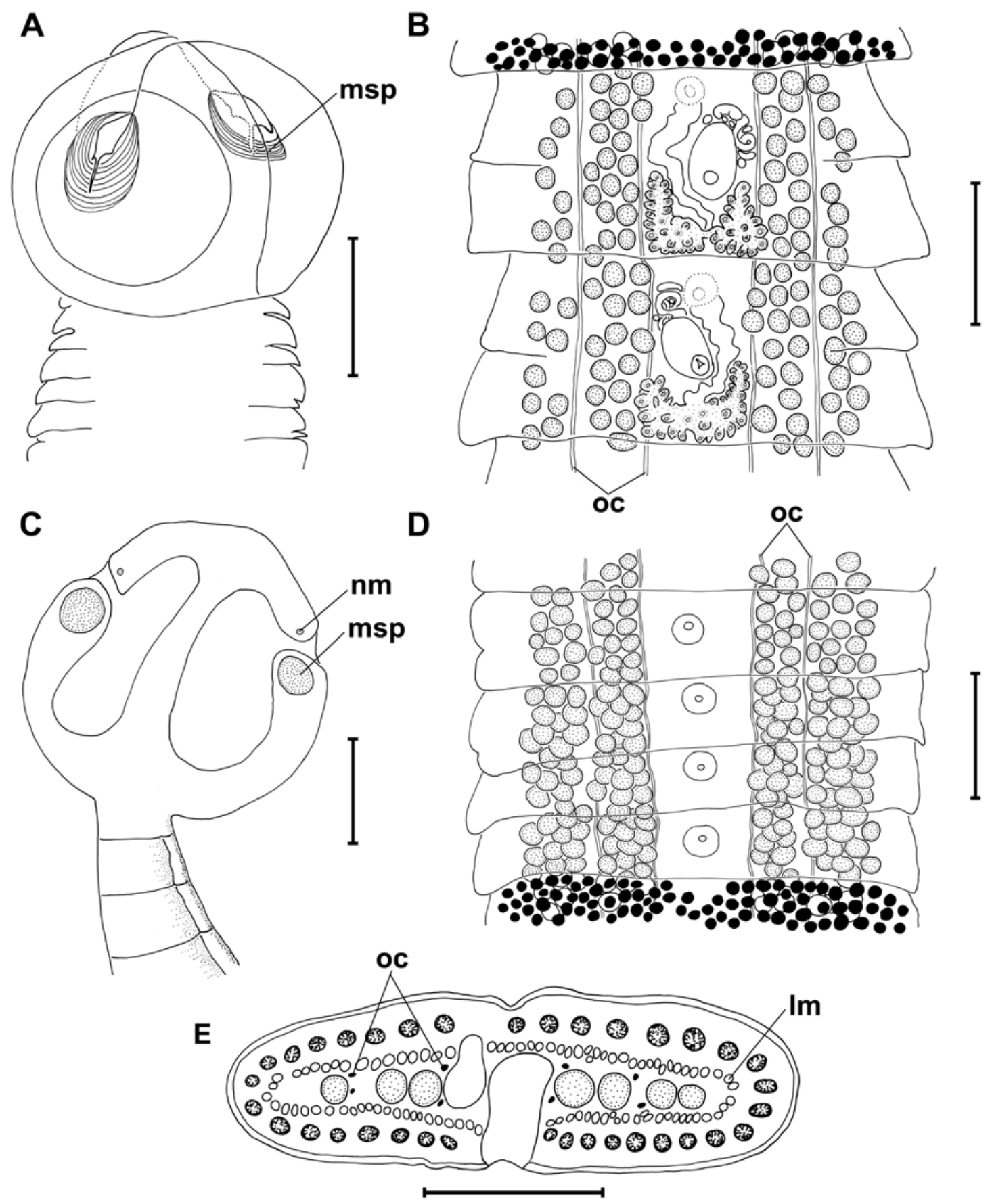

Fig. 7. Clestobothrium crassiceps (Rudolphi, 1819) from Merluccius merluccius, schematic drawings. A - scolex showing musculature of bothria; dorsoventral view, vouchers (BMNH 1976.4.12.152-154); B - mature proglottides, vitelline follicles only illustrated in anterior proglottis; dorsal view, voucher (BMNH 1989.7.6.17); C - scolex showing musculature of bothria; lateral view, syntype (ZMB "Vermes" E-1807); D - mature proglottides, vitelline follicles only illustrated in posterior proglottis; dorsal view, syntype (ZMB "Vermes" E-1807); E - transverse cross-section of mature proglottis at level of uterine pore; syntype (ZMB "Vermes" E-1807). Abbreviations: $1 \mathrm{~m}$ - bundles of longitudinal musculature; msp - muscular sphincter; $\mathrm{nm}$ - narrow muscle; oc - osmoregulatory canals. Scale bars: A, C $=500 \mu \mathrm{m} ; \mathrm{B}, \mathrm{D}=250 \mu \mathrm{m} ; \mathrm{E}=300 \mu \mathrm{m}$.

Testes medullary, spherical to slightly oval $40-100$ (62) $(\mathrm{n}=33)$ in diameter; 39-64 (49) $(\mathrm{n}=10)$ per mature proglottis, distributed in 1 layer occupying 2 lateral fields, each one divided into one wide internal field and one narrow external field, best distinguishable in immature and first mature proglottides. Testes continuous from proglottis to proglottis, usually completely surrounding ovary posteriorly (Fig. 5C, E, F). Genital pore dorsal, submedian, rounded, at same level of spurious articulations when present (Fig. 6F), situated $32-62 \%(48 \%)(n=42)$ from 
anterior margin of mature proglottis; genital atrium not observed. Cirrus-sac oval to globular, small, thick-walled, irregularly alternating dextrally or sinistrally to median line in successive proglottides, 70-120 (88) $\times$ 60-80 (71) $(\mathrm{n}=14)$ in diameter, occupying $8-16 \%(10 \%)(\mathrm{n}=12)$ of proglottis width in mature proglottides (Fig. 5C). Cirrus unarmed occupying $40-50 \%$ of cirrus-sac length. Seminal vesicle not observed. Vas deferens strongly coiled, situated anterolaterally (Fig. 5C, E).

Ovary medullary, post-equatorial, bilobed, slightly folliculate, transversely elongated or slightly U-shaped 200-400 (245) ( $\mathrm{n}=44)$ wide; occupying 22-49\% (29\%) $(\mathrm{n}=44)$ of proglottis width in mature proglottides (Fig. $5 \mathrm{C}, \mathrm{F}$ ). Vaginal canal situated between ovary lobes, vaginal sphincter and seminal receptacle not observed (Fig. $5 \mathrm{C}, \mathrm{F})$. Vitelline follicles densely distributed in one circumcortical layer, forming continuous field around margins of proglottis in transverse section and from proglottis to proglottis; interrupted dorsally at level of genital pore and ventrally at level of uterus when gravid. Follicles spherical to oval 30-60 (45) $(n=24)$ in diameter in mature proglottides (Figs. 1B, 5C, E, F). Uterus tubular, almost straight, irregularly alternating dextrally or sinistrally to midline; enlarged in gravid proglottides, forming a uterine-sac occupying $12-45 \%(26 \%)(n=38)$ of gravid proglottis width, usually extends towards preceding proglottis. Uterine pore ventral, median to submedian, at anterior margin of proglottis, generally overlapped by velum-like posterior margin of preceding proglottis in mature proglottides (Figs. 5C, 6G). Eggs oval 60-65 $\times$ $40-45(\mathrm{n}=4)$, unembryonated, with inconspicuous operculum (Fig. 5D).

Type host: Merluccius hubbsi Marini (Gadiformes: Merlucciidae); vernacular names "merluza argentina", "merluza común" or "merluza bonaerense" in Argentina, "Atlantic hake" in the United Kingdom.

Type locality: Patagonian shelf $\left(50^{\circ} 98^{\prime} \mathrm{S} ; 67^{\circ} 38^{\prime} \mathrm{W}\right)$, Atlantic Ocean, Argentina.

Other 1 ocality: San Matías Gulf $\left(41^{\circ} 45^{\prime} \mathrm{S} ; 64^{\circ} 30^{\prime} \mathrm{W}\right)$, Atlantic Ocean, Argentina.

Type materia 1: Holotype MACN-Pa No. 511/1, paratypes MACN-Pa No. 511/2-3, IPCAS C-601 (3 worms: 2 entire and 1 without scolex), ZMB "Vermes" E-7430.

Site of infection: Intestine.

Infection indices: In Patagonian shelf, prevalence $25 \%$ (2/8), intensity 1 worm per fish; in San Matías Gulf, prevalence $29 \%(6 / 21)$, intensity $1-6$ worms per fish.

Etymology: The species is named after Mrs. Cristina Banchero, a friend of one of the authors (A. A. G. de P.).

Remarks. The new species is assigned to Clestobothrium because it has the scolex features above mentioned and the diagnostic characteristics of this genus given by Bray et al. (1994) and Kuchta et al. (2008).

Clestobothrium cristinae is typified by the following combination of characters: all the proglottides being much wider than long; presence of two types of microtriches on the tegument surface (capilliform filitriches and gladiate spinitriches); a rounded genital pore without atrium situated at $32-62 \%$ from the anterior margin of mature proglottides; 39-64 testes, usually completely surrounding the ovary posteriorly; an oval cirrus-sac occupying $8-16 \%$ of mature proglottis width; and three pairs of osmoregulatory canals on each side of the proglottis; a post-equatorial, bilobed, slightly folliculate ovary, elongated transversely or curved slightly towards the anterior margin of the proglottis; a vagina without sphincter; and unembryonated eggs with inconspicuous operculum.

The new tapeworm is distinguished from $C$. gibsoni and $C$. neglectum by having three pairs of osmoregulatory canals on each side of the proglottis (vs. two pairs), its smaller size (17-59 $\mathrm{mm}$ vs. $120-145 \mathrm{~mm}$ and $98-125$ $\mathrm{mm}$, respectively), and by the number of proglottides (71219 vs. 500-600 and 725-770, respectively) and testes (39-64 vs. 60-65 and 70-90, respectively). In addition, the new species differs from $C$. gibsoni in the distribution of testes (two lateral fields, each one divided into one wide internal field and one narrow external field vs. two undivided lateral fields) and the distribution of vitelline follicles (one layer vs. 2-3 layers as shown by Dronen and Blend 2005 fig. 5). Clestobothrium cristinae is also distinguished from $C$. neglectum in that its proglottides do not show a scalloped pattern of longitudinal ridges across the ventral and dorsal surfaces.

Clestobothrium cristinae differs from C. crassiceps in the location and morphology of the ovary (post-equatorial and slightly folliculate vs. posterior and markedly folliculate), the distribution of testes (usually surrounding completely the ovary posteriorly vs. not surrounding the ovary posteriorly), the number of the osmoregulatory canals on each side of the proglottis (three pairs vs. two pairs) and the shape of the uterus (almost straight vs. sinuous).

The new species shares with $C$. splendidum the number and distribution of osmoregulatory canals and the type of microtriches (capilliform filitriches and gladiate spinitriches), but differs in the distribution of microtriches on the apical surface between the lips (capilliform filitriches interspersed with gladiate spinitriches vs. only capilliform filitriches), its smaller size and lower number of proglottides, the length/width ratio of the proglottis (immature 1:0.15-0.55 vs. 1:0.12-0.22, mature 1:0.22-0.58 vs. 1:0.16-0.27, and gravid 1:0.30-0.90 vs. 1:0.16-0.26), the location of the testes relative to the ovary (usually completely surrounding the ovary posteriorly vs. few of them posteriorly to ovary in some proglottides), shape and proglottis width/cirrus-sac length ratio (oval, occupying $8-16 \%$ vs. globular, occupying 4-7\%), location of the ovary (post-equatorial vs. equatorial), vaginal sphincter (absent vs. present), genital atrium (absent vs. present), and fish host (M. hubbsi vs. M. australis). 


\section{DISCUSSION}

There is little information on bothriocephalidean tapeworms parasitizing fishes of the continental shelf of Argentina, with only a few species being recorded from marine teleosts, i.e. Anonchocephalus argentinensis Szidat, 1961; A. chilensis Riggenbach, 1896 and A. patagonicus Suriano et Labriola, 1998 (see Szidat 1961, Suriano and Labriola 1998). Furthermore, Galaxitaenia toloi Gil de Pertierra et Semenas, 2005 and Ailinella mirabilis Gil de Pertierra et Semenas, 2006 from freshwater teleosts have been described recently (see Gil de Pertierra and Semenas 2005, 2006).

Several authors (e.g. Cooper 1918, Wardle 1935, Rees 1958, Bray et al. 1994) did not mention the presence of an apical disk in the scolex of $C$. crassiceps. However, scanning electron micrographs show a weekly developed apical disk in worms from $M$. merluccius (see Kuchta et al. 2008; fig. 1K) and in the two species described in the present study.

The study of the tegument surface of the two new species of Clestobothrium shows that they share the same type and distribution of microtriches, with only slight differences being observed on the surface of the apex of the scolex between the lips. The large gladiate spinitriches on part of the scolex and posterior margin of the proglottides in C. splendidum and C. cristinae have already been seen with light microscope in C. crassiceps (see Cooper 1918) and C. neglectum (see Dronen and Blend 2003). This type of microtriches also seem to be present in C. gibsoni, as they were drawn (though not mentioned in the text) by Dronen and Blend (2005; figs. 2, 4). Based on these considerations, the microtriches of Clestobothrium spp. may follow a similar pattern. In regard to SEM studies of the surface of bothriocephalidean cestodes, only a few have covered the entire scolex (e.g. Gil de Pertierra and Semenas 2005, 2006), and, until this work, the proglottis has not been investigated in detail with no information being provided, for example, on microthrix distribution.

The study of the Bothriocephalidea presents numerous difficulties (Kuchta et al. 2008), the most important being their homogeneous morphology. There are, notwithstanding, a few characters that can be used for the diagnosis and differentiation among the members of this order. For example, $C$. crassiceps and $C$. cristinae bear a strong morphological resemblance to each other and show a considerable overlap in some measurements but the location and morphology of the ovary, the distribution of the testes and the number of osmoregulatory canals can be regarded as good differential characters.

The specimens of Clestobothrium sp. (BMNH 1989.1.5.25-30) from Merluccius sp. collected off the Malvinas Islands could not be assigned to either of the two new species described in this paper or C. crassiceps. These specimens are in poor condition (worms incom- plete, overstained, contracted and vacuolated), but their large size suggests they could be $C$. splendidum.

As mentioned above, the bothriocephalidean parasitizing hakes from the continental shelf of Argentina, Chile and Peru was assigned to C. crassiceps (e.g. MacKenzie and Longshaw 1995, Sardella and Timi 1996, 2004, Oliva and Ballón 2002, George-Nascimento 2005). This parasite was also found in other marine fishes from the continental shelf of Chile (Oliva 2001, Cortés and Muñoz 2009) and in the cape hakes $M$. capensis Castelnau and M. paradoxus Franca from the southeast Atlantic Ocean, near Namibia (Reimer 1993). The spectrum of hosts of C. crassiceps in the Southern Hemisphere should be reconsidered in the light of the new species harboured by $M$. australis and $M$. hubbsi. This implies the necessity of collecting new material appropriate for taxonomic studies.

\section{Key to the species of Clestobothrium}

1 Testes arranged in two undivided lateral fields. Vitelline follicles distributed in 2-3 layers, host Bathygadus macrops ... C. gibsoni

- Testes arranged in two lateral fields, each one divided into two fields. Vitelline follicles distributed in one layer ........ 2

2 Testes completely surrounding the ovary posteriorly ........ 3 - $\quad$ Testes partially or not surrounding the ovary posteriorly .. 4

3 Surface of proglottides highly folded forming a scalloped pattern. Strobila longer than $90 \mathrm{~mm}$, composed of more than 700 proglottides, host Raniceps raninus ........ C. neglectum - Surface of proglottides without a scalloped pattern. Strobila shorter than $60 \mathrm{~mm}$, composed of less than 220 proglottides, host Merluccius hubbsi ............................... C. cristinae

4 Total number of testes 49-90. Genital atrium and vaginal sphincter present, host Merluccius australis

C. splendidum

- Total number of testes 36-52. Genital atrium and vaginal sphincter absent, host Merluccius merluccius and M. bilinearis. C. crassiceps

Acknowledgements. We thank Dr. B. Neuhaus (Museum für Naturkunde, Zentralinstitut der Humboldt-Universität, Berlin, Germany) for loan of type material of Clestobothrium crassiceps and for allowing us to make a whole-mount preparation of one specimen. We also thank Dr. David Gibson and Mrs. Eileen Harris (both from BMNH) for loan of voucher material of Clestobothrium crassiceps and Ms. Xenia Sergejew for translating Russian articles. Special thanks are due to the two anonymous referees for their valuable comments that helped to improve this paper. Research was supported by ANPCyT (Proj. BID 1728 OC-AR PICT No. 825) and Universidad de Buenos Aires (Grants UBACYT - X443, X453, 20020090200511 and 20020090200529). 


\section{REFERENCES}

BOYCE R.P. 1976: A new organ in cestode surface ultrastructure. Can. J. Zool. 54: 610-613.

Bray R.A., Jones A., Andersen K.I. 1994: Order Pseudophyllidea Carus, 1863. In: L.F Khalil, A. Jones and R.A. Bray (Eds.), Keys to the Cestode Parasites of Vertebrates. CAB International, Wallingford, UK, pp. 205-247.

Carvajal J., Cattan P.E., Castillo C., Schatte P. 1979: Larval anisakids and other helminths in the hake, Merluccius gayi (Guichenot) from Chile. J. Fish Biol. 15: 671-677.

Chervy L. 2009: Unified terminology for cestode microtriches: a proposal from the International Workshops on Cestode Systematics in 2002-2008. Folia Parasitol. 56: 199-230.

COOPER A.R. 1918: North American pseudophyllidean cestodes from fishes. Ill. Biol. Monogr. 4: 1-243.

CoRTÉs Y., Muñoz G. 2009: Metazoan parasite infracommunities of the toadfish Aphos porosus (Pisces: Batrachoidiformes) in Central Chile: how variable are they over time? J. Parasitol. 95: 753-756.

Dronen N.O., Blend C.K. 2003: Clestobothrium neglectum (Lönnberg, 1893) n. comb. (Cestoda: Bothriocephalidae) from the tadpole fish Raniceps raninus (L.) (Gadidae) from Sweden. Syst. Parasitol. 56: 189-194.

Dronen N.O., Blend C.K. 2005: Clestobothrium gibsoni n. sp. (Cestoda: Bothriocephalidae) from the bullseye grenadier Bathygadus macrops Goode \& Bean (Macrouridae) in the Gulf of Mexico. Syst. Parasitol. 60: 59-63.

Fernández J. 1985: Estudio parasitológico de Merluccius australis (Hutton, 1872) (Pisces: Merlucciidae): aspectos sistemáticos, estadísticos y zoogeográficos. Bol. Soc. Biol. Concepción 56: $31-41$.

Froese R., Pauly D. (Eds.) 2010: FishBase. World Wide Web electronic publication. www.fishbase.org, September 2010.

George-Nascimento M. 2005: Population and assemblages of parasites in hake, Merluccius gayi, from the southeastern Pacific Ocean: stock implications. J. Fish Biol. 48: 557-567.

Gil de Pertierra A.A., Semenas L.G. 2005: Galaxitaenia toloi n. gen., n. sp. (Eucestoda: Pseudophyllidea) from Galaxias platei (Pisces: Osmeriformes, Galaxiidae), in the Patagonian region of Argentina. J. Parasitol. 91: 900-908.

Gil de Pertierra A.A., Semenas L.G. 2006: Ailinella mirabilis gen. n., sp. n. (Eucestoda: Pseudophyllidea) from Galaxias maculatus (Pisces: Galaxiidae) in the Andean-Patagonian region of Argentina. Folia Parasitol. 53: 276-286.

Kuchta R., Scholz T. 2007: Diversity and distribution of fish tapeworms of the "Bothriocephalidea" (Eucestoda). Parassitologia 49: 129-146.

Kuchta R., Scholz T. 2008: A new triaenophorid tapeworm, Milanella familiaris $\mathrm{n}$. gen. and $\mathrm{n}$. sp. (Cestoda: Bothriocephalidea), from blackfish Centrolophus niger. J. Parasitol. 94: 500504.

Kuchta R., Scholz T., Bray R.A. 2008: Revision of the order Bothriocephalidea Kuchta, Scholz, Brabec \& Bray, 2008 (Eucestoda) with amended generic diagnoses and keys to families and genera. Syst. Parasitol. 71: 81-136.

Kuchta R., Scholz T., Vlčková R., Ř́iha M., Thorsten W., YuNiar A.T., PALm H.W. 2009: Revision of tapeworms (Cestoda:
Bothriocephalidea) from the lizardfish (Saurida: Synodontidae) from the Indo-Pacific region. Zootaxa 1977: 55-77.

Langeron M. 1949: Précis de Microscopie. 7th Ed. Masson \& Cie, Paris, $1429 \mathrm{pp}$.

MacKenzie K., Longshaw M. 1995: Parasites of the hakes Merluccius australis and M. hubbsi in the waters around the Falkland Islands, southern Chile, and Argentina, with an assessment of their potential value as biological tags. Can. J. Fish. Aquat. Sci. 52 (Suppl. 1): 213-224.

Oliva M.E. 2001: Metazoan parasites of Macruronus magellanicus from southern Chile as biological tags. J. Fish Biol. 58: $1617-1622$.

Oliva M.E., Ballón I. 2002: Metazoan parasites of the Chilean hake Merluccius gayi gayi as a tool for stock discrimination. Fish. Res. 56: 313-320.

Pool D.W. 1987: A note on the synonymy of Bothriocephalus acheilognathi Yamaguti, 1934, B. aegyptiacus Ryšavý and Moravec, 1975 and B. kivuensis Baer and Fain, 1958. Parasitol. Res. 73: 146-150.

Protasova E.N. 1977: [Bothriocephalata - Tapeworm Helminths of Fish.]. K.M. Ryzhikov (Ed.), Principles of Cestodology, Vol. 8. Nauka, Moscow, 298 pp. (In Russian.)

REES G. 1958: A comparison of the structure of the scolex of Bothriocephalus scorpii (Müller 1776) and Clestobothrium crassiceps (Rud. 1819) and the mode of attachment of the scolex to the intestine of the host. Parasitology 48: 468-492.

Reimer L.W. 1993: Parasites of Merluccius capensis and M. paradoxus from the coast of Namibia. Appl. Parasitol. 34: 143-150.

RUDOLPHI C.A. 1819: Entozoorum synopsis cui accedunt mantissa duplex et indices locupletissimi. Berolini, $821 \mathrm{pp}$.

Sardella N.H, Timi J.T. 1996: Parasite communities of Merluccius hubbsi from the Argentinian-Uruguayan common fishing zone. Fish. Res. 27: 81-88.

Sardella N.H, Timi J.T. 2004: Parasites of Argentine hake in the Argentine Sea: population and infracommunity structure as evidence for host stock discrimination. J. Fish Biol. 65: 14721488.

SChмidt G.D. 1986: Handbook of Tapeworm Identification. CRC Press, Boca Raton, Florida, USA, 675 pp.

Suriano D.M., Labriola J.B. 1998: Redescription of Anonchocephalus chilensis (Riggenbach, 1896) (Pseudophyllidea: Triaenophoridae) and description of A. patagonicus n. sp. Bol. Chil. Parasitol. 53: 73-77.

Szidat L. 1955: La Fauna de parásitos de "Merluccius hubbsi" como carácter auxiliar para la solución de problemas sistemáticos y zoogeográficos del género "Merluccius" L. Comun. Inst. Nac. Invest. Cienc. Nat. Mus. Arg. Cienc. Nat. "Bernardino Rivadavia" $3:$ 1-54.

Szidat L. 1961: Versuch einer Zoogeographie des Süd-Atlantik mit Hilfe von Leitparasiten der Meeresfische. Parasitol. Schriftenreihe 13: 1-98.

Wardle R.A. 1935: The Cestoda of Canadian Fishes III. Additions to the Pacific Coastal Fauna. Contrib. Can. Biol. Fish. 8: 79-87.

Yamaguti S. 1959: Systema Helminthum. Vol. II. The Cestodes of Vertebrates. Interscience Publishers Inc., New York, USA, $860 \mathrm{pp}$.

Accepted 15 January 2011 